\title{
The Irish Education System and Implications for the Turkish Education System
}

\author{
Nuriye Karabulut \\ Faculty of Educational Sciences, Ankara University, Turkey
}

\section{Introduction}

During recent years, due to the effects of globalization and technological developments, countries around the world are influencing each other in education as well as in many other fields such as sports, arts and politics. It is possible to say that the member states in the European Union have increased this interaction with applications such as the Bologna Process and that they are moving towards certain standardization in the field of education. On the other hand, while the education systems of that countries are similar to some extent, they have also various differences. In other words, the educational system of each country has strengths and weaknesses. In this respect, it is very important to examine and understand existing educational systems and to express differences by comparison. Thus, a country can adapt the strengths of the other countries' education systems to its own education system and develop in this way. In this connection, the current study aimed to present an outline of the education system of Ireland, one of the European Union members, and to elicit its differences from and similarities to the Turkish education system.

\section{Geographical, Social, Political and Economic State of Ireland}

Ireland, the first colonial region of Britain and fighting against the United Kingdom for many years, gained its independence in 1922 (Şöhret, 2013; Yeter, 2004). According to the Law of the Republic of Ireland issued in 1948, it was decided to call the state "Republic of Ireland". Nevertheless, the use of "Ireland" is more common to refer to the unity of Ireland (Embassy of the Republic of Turkey [DBTM], 2010)

Ireland is an island state with an area of $70.280 \mathrm{~km}^{2}$, having a width of about $225 \mathrm{~km}$ and a length of $362 \mathrm{~km}$ (Ministry of Economy, 2014). In the north east of the country is there Northern Ireland; in the west is there the Atlantic Ocean and in the east is there the Irish Sea. The total length of the country's shores is $1.448 \mathrm{~km}$. Its sole land 
neighbor is Northern Ireland, which is under the sovereignty of the UK government. The capital city of Ireland is Dublin. Other important cities are Galway, Cork and Limerich (Istanbul Chamber of Commerce, 2009; Ministry of Economy, 2014).

Temperate marine climate prevails in Ireland (Istanbul Chamber of Commerce, 2009). Despite the fact that the majority of the country's vegetation is made up of meadows and pastures, it is also called "emerald island" because it has a green image at all seasons (DBTM, 2010). Ireland has one of the world's largest lead / zinc deposits. There are also fuel reserves called "peat", which is a kind of vegetable residue, and it has an important place in the country (Ministry of Economy, 2014).

Ireland is governed by parliamentary democracy. The parliament is constituted by members of the parliament and senate members. State administration is based on the principle of separation of powers. The Irish Constitution regulates the authorities and duties of the president and parliament and structure and functioning of courts, and secures basic citizenship rights (Ministry of Economy, 2014). In Ireland, the law is made up of rulings and laws passed by the parliament on the basis of the Constitution. Moreover, regulations of the European Union have been put into effect in the country (DBTM, 2010).

In Ireland, the state has no official religion. Yet, $87.4 \%$ of the population is Catholic, $2.9 \%$ is Protestant, and $9.7 \%$ belongs to other religions. Of the adult population, $95 \%$ are literate and Ireland has two official languages. According to the Irish Constitution the first official language of the state is Irish, the second official language is English (DBTM, 2010). Ireland has a continuously growing population structure. The population structure of Ireland is shown in Table 1.

Table 1. Distribution of Ireland population across age groups

\begin{tabular}{lc}
\hline Age group & Population \\
\hline 0 - 14 years old & $1,029,400$ \\
15 - 24 years old & 516,700 \\
25 - 44 years old & $1,377,600$ \\
45 - 64 years old & $1,105,900$ \\
65 years old or older & 606,000 \\
Total population & 4.635 .400 \\
\hline
\end{tabular}

Source: Ireland Central Statistics Institution, 2015.

When Table 1 is examined it is possible to say that Ireland has a young and dynamic population structure. As a matter of fact, people aged 65 and over constitute the smallest section of the country's population. The total population is $4,635,400$. Of 
this total population, 2,345,800 are females and 2,289,500 are males (Ireland Central Statistical Office, 2015).

The most densely populated area of the country is Dublin in that nearly $60 \%$ of the whole population lives in and around Dublin. Among the European Union countries, Ireland is the country with the highest population growth rate. The greatest reason for this increase is the immigration to Ireland from countries such as Poland, Romania, which have recently joined the European Union. Thus, it is estimated that the Irish population will increase to over 5.7 million by 2026 (DBTM, 2010).

Ireland, which has adopted liberal economic policy, has used Euro since its currency since 2002 . Approximately $61.8 \%$ of Ireland's national income comes from services, $35.3 \%$ from industries and $2.9 \%$ from agriculture. Export is also very important for the Irish economy. Ireland has annual export revenue of approximately 80 billion Euros. On the other hand, the unemployment rate of $11 \%$ in Ireland should not be underestimated (Ministry of Foreign Affairs, 2016).

\section{Irish Education System}

Under this heading, the policies and objectives of the Irish Education System are addressed, the structure of the education system is examined on the basis of the administrative and school structure and the process dimension of the education system is outlined.

\section{Educational Policies and Objectives}

Article 42 of the Irish Constitution clearly states the state's educational policy and the responsibilities imposed on the state in relation to education. According to the Constitution, the state is obliged to observe the best interests of the child and must comply with the following principles (Ministry of Justice, 2011):

- The state recognizes that parents have the right to determine their children's education and secures the right and the duty of parents to provide education for their children in terms of mental, physical, social, religious and moral development.

- Parents can provide education for their children in their own homes as well as in private schools and state schools that are established or recognized by the state. 
- The state cannot force its parents to send their children to a particular type of school, ignoring their conscience and preferences. However, the state, which is obliged to observe the public interest, has to ensure that children receive a certain minimum education in terms of their mental, moral and social development.

- The state provides free primary education, and it helps private and large institutional educational initiatives to a reasonable extent; allows pupils to receive training in other educational establishments or institutions, in particular taking into account the concerns of their parents about religious and moral education of their children.

- If parents fail to fulfill their duties to their children, the state tries to fulfill the duties of the parents by taking care of the child's interest.

It can be seen the state gives the right to educate their children primarily to parents and let them free in selecting the school for their children in line with their own beliefs and preferences. Parents are even given the right to educate their children at home. The state, however, makes the necessary interventions in the event that the public interest and the best interests of the child are violated. The Irish state is particularly concerned with the provision of the minimum level of education for every child and continuity of their schooling and develops policies to ensure this to happen. In this respect, in 2000, the Educational Welfare Law was passed, and the Educational Welfare Unit was established within the context of this law to monitor the children's attendance to the school and investigate the reasons for absenteeism and in order to prevent this, supportive activities have been carried out in cooperation with education stakeholders (Ballidere, 2012).

The overall aim of the Irish Education System is to contribute to the aesthetic, social, creative, critical, cultural, emotional, mental, moral, physical, and political development of individuals so that they can benefit themselves, their families, labor force and society (ec.europa.eu). Indeed, the Department of Education and Skills (DES) states that its mission is to facilitate the lives of individuals through learning, to enable individuals to realize their potential, and to contribute to the social, cultural and economic development of Ireland. Within this mission, the general objectives of DES are expressed as follows (www.education.ie):

- Learning for life. It is aimed to create a system of education and training that will give people the knowledge and skills to enable them to become a part of society and economic life.

- Enhancing quality and accountability. It is aimed to ensure that everyone receives a quality education and training and to increase accountability in the educational process. 
- Promoting differences and participation. It is aimed to create an education system that cares about the needs of people with different cultural, linguistic and social backgrounds, disabled people and people with special needs and disadvantaged people and meet their needs.

- Formation of a correct system and infrastructure. It is aimed to create a modern and flexible education and training system that enables the best use of resources.

It can be seen, the Irish Education System aims at taking individual differences into account, ensuring equality, eliminating educational disadvantages, increasing quality of life and developing policies in this direction (Erginer, 2009). In this regard, the general objectives of the elementary education can be expressed as follows (www.education.ie):

- To enable the child to "live like a child" and to be aware of his/her potential as a unique person.

- To ensure that the child can co-exist and collaborate with other children to become a social entity.

- To lay the ground for the development of a continuous learning understanding in the child.

The general aim of lower secondary education is to develop and deepen knowledge, skills and competences acquired at primary level. At the same time, it aims to help young people in secondary and lower secondary education to have social and personal self-esteem, to be a competent person, to be able to take initiative and to contribute to their spiritual and moral development. In line with these objectives, lower secondary education tries to prepare students for business and social lives and to ensure that they are good and active citizens at the local, national, European and global level (ec.europa.eu).

The aim of upper secondary education is to ensure that students are active citizens in the society, to help them actualize their personal, social, intellectual and professional potentials and to prepare them for the next level of education or business life (ec.europa.eu). The higher education aims to educate individuals who have the qualifications to meet the requirements of the age. To this end, various plans are being prepared. For example, in 2011, a plan called "National Strategy for 2030 Higher Education" was established. According to this plan, the Irish higher education, in 20 years' time: (DES, 2006);

- Will be a flexible system that can meet the continuously diversifying learning needs of students who will have many choices to select, 
- Will be able to increase students' experiences related to educationalinstructional processes and outcomes.

\section{Structure of the Education System}

Under this heading, the administrative structure and school structure of the Irish Education System are discussed. School structure is examined as preschool education, primary education, secondary education, higher education, advanced and adult education and special education.

Administrative structure. The Irish Education System has a centralized structure and DES is the main body responsible for education and instruction (www.education.ie). DES particularly takes all the responsibilities for primary, secondary and special education. In addition, state support given to the higher education institutions is also provided through the relevant unit within the Ministry (ec.europa.eu). Administrative structure of DES is shown in Figure 1.

As can be seen in Figure 1, the highest-level authority of the ministry is the minister, then the secretary general follows him/her. Under the chairmanship of the secretary general, seven assistant secretaries general, a deputy secretary and a chief inspector are in charge of various departments (www.education.ie).

As shown in Figure 1, there are 40 units and departments in the senior management of DES. These units and departments have sub-units or different institutions that they work with (National Curriculum and Evaluation Committee, Higher Education Council etc.). Duties of DES are clearly stated in the Irish Education Law. According to this law, the main duties of DES are as follows (Ballidere, 2012):

- To ensure that all people living in Ireland, including people with disabilities, receive training according to their abilities and needs,

- To determine national educational policies,

- To plan and coordinate the educational services provided at schools and other training centers,

- To evaluate the given education services in terms of quality, efficiency and effectiveness and share the results with the public,

- To rent state property to applicants or establishments for the purpose of establishing a school, ensuring that they are recognized and supported,

- To cooperate with educational stakeholders such as school councils and unions to make the optimal use of existing resources while performing its duties,

- To prepare school curricula and central exams, 
- To establish laws and regulations in the field of education,

- To eliminate the deficiencies of schools, to transfer resources and personnel and to arrange teacher salaries,

- To provide financial support for social and sporting activities for young and adults outside formal education.

Figure 1. Administrative Structure of DES in Ireland

Source: $w w w . e d u c a t i o n . i e$

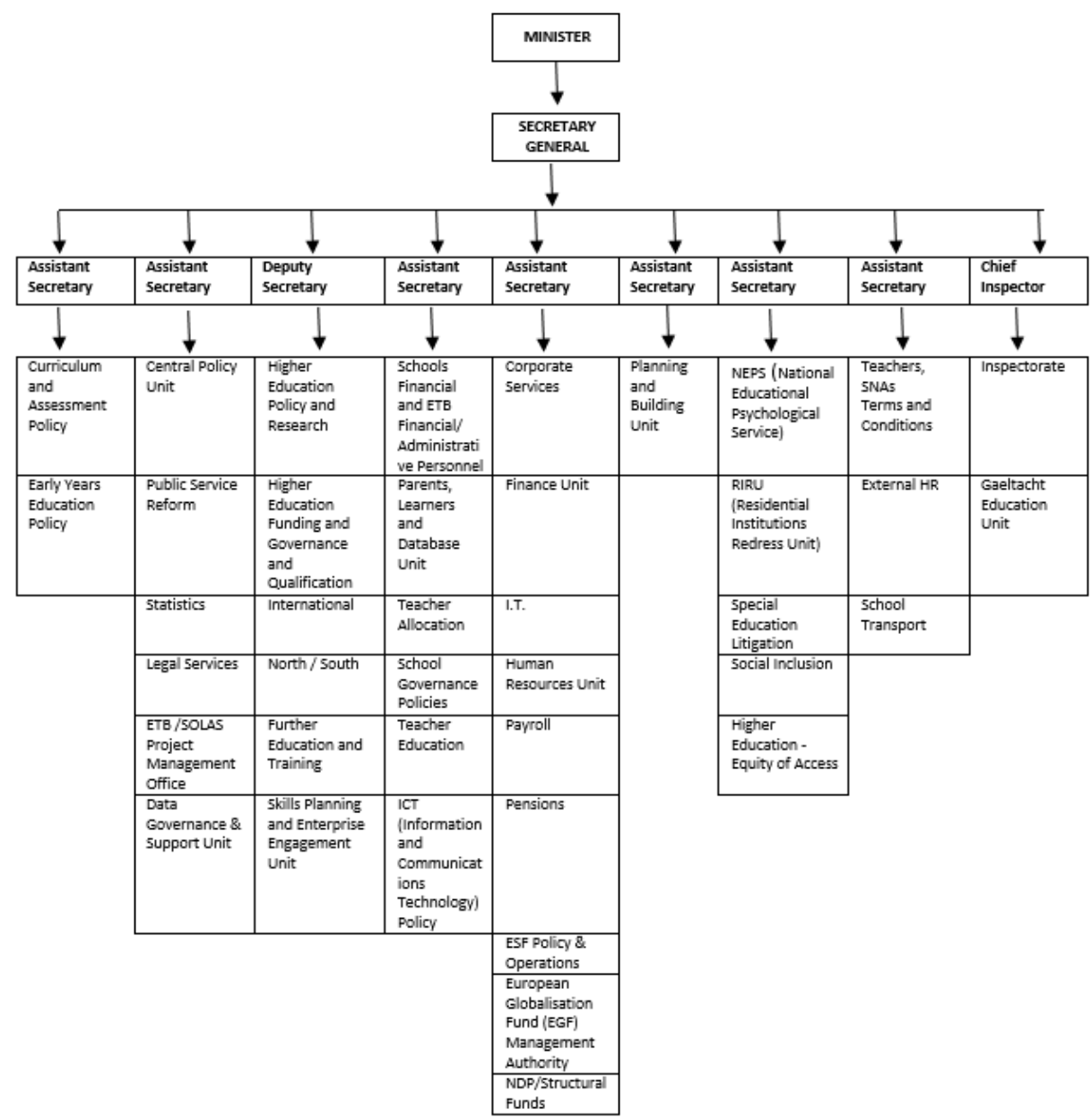

It can be seen, it is possible to say that DES has a wide range of authorities and duties, such as determining national education policy and legislation, supervising the education system and financing for education. In addition, emphasis put on the cooperation of the Ministry with the stakeholders of education in the relevant law is an indication of the importance attached to the participation of these stakeholders in 
education. In this regard, DES is different from other ministries. It is known that there are about 120 institutions working in co-operation with DES in educational and instructional issues. Parents' associations, student unions, adult education organizations, institutes, workers' organizations and various professional organizations are some of them. The expectations of these organizations may conflict from time to time. The Ministry has a fair and conciliatory approach in such cases (Erginer, 2009).

As stated before, DES has a centralized management structure and has begun to adopt the concept of strategic management since 1994 (ec.europa.eu.). The debate over this centralized structure of the Ministry and efforts for its decentralization are continuing (Ballidere, 2012). However, it should be noted that the Ministry does not have a very strict central management approach. For example, although most schools are funded by the state, they have the freedom to form their own staff (MarlowFerguson, 2002). The management staff of schools is usually made up of the school owner (boss), board of directors and directors. The school owner is responsible for issues such as ownership and philosophy of the school; the board of directors is held responsible for issues such as selecting the staff and adherence to regulations and the school director is held responsible for the daily works of the school (Ballidere, 2012).

Structure of the school system. The Irish education system is made up of three levels. The first level is primary education, the second level is secondary education and the third level is higher education. This school system is shown in Figure 2.

As can be seen in Figure 2, primary education in Ireland includes children aged 612 years and is compulsory. Secondary school covers a three-year lower secondary school for children aged 12-15 years old and two or three-year upper secondary school for children aged 15-18 years old. The upper secondary education may continue two or three years because there is a "transition year" that is optional. While primary education and lower secondary education are compulsory because compulsory education in Ireland covers the 6 to 16 age range, continuing upper secondary education is volitional (www.education.ie).

Pre-school education. Education and care services for children in early childhood (0-4 years) are excluded from formal education. Pre-school education is usually provided in specially financed child care centers. The Ministry of Child and Youth Affairs is primarily responsible for the care and education of the children in this period. DES supports this ministry and works in cooperation with it. In this connection, in order to increase the participation of especially children at risk oneyear free education and care service has started to be given to children aged 3-4 from 2010 (www.citizensinformation.ie). 


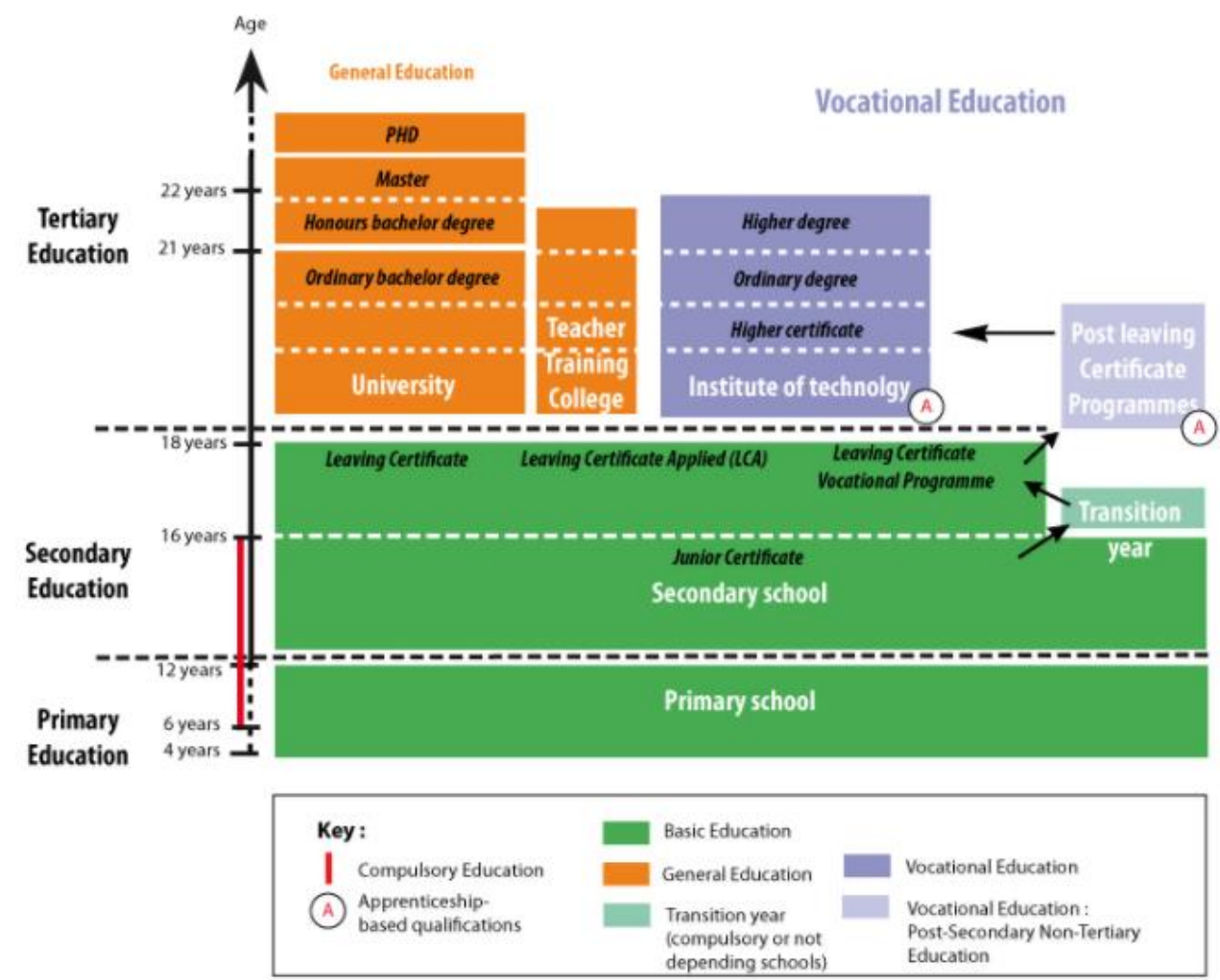

Figure 2. Irish Education System

Source: $\underline{\text { mavoieproeurope.onisep.fr }}$

The pre-school educational and training services are optional. In addition, children aged 4 years old can receive kindergarten education in elementary schools. Approximately $40 \%$ of children aged 4 years old and almost all of children aged 5 years old continue to these kindergartens where preschool education is provided. It is therefore possible to say that pre-school education in Ireland covers children aged 4-6 years old.

Primary education. In Ireland, primary education is the first stage of compulsory education, including the age range of 6-12. However, as the primary education also includes the children aged 4 to 6-year-olds attending kindergartens, it is seen as an eight-year period covering the age range of 4-12. Primary education consists of "primary schools financed by the state", "private primary schools run by free enterprises" and "special primary schools". State financed schools are divided into groups among themselves. These are religious schools, non-denominational schools and Irish-medium schools called "Gaelscoileanna". Due to historical reasons, most schools are religious schools. Religious schools are under the influence of the church 
and even owned by them and their management committees are made up largely of members of religious communities. The only language of education in Irish secondary schools is Irish. Despite all these differences, however, all the statefinanced schools are subject to the curriculum established by the DES and the schools are supervised by the Ministry's Inspection Board. Privately owned primary schools have to follow a curriculum similar to that of other schools but they do not receive government support (www.education.ie; ec.europa.eu; www.citizensinformation.ie).

There are 3152 primary schools in Ireland. Aside from the classifications mentioned above, these schools can be classified by gender. Though not many in number, there are "primary schools for girls" and "primary schools for boy". Though such genderbased schools were considered to be normal in the past, they have begun to be converted into co-educational schools. Now, nearly $80 \%$ of the primary schools are co-educational schools (ec.europa.eu).

Secondary education. Children aged 12 years old who have completed primary education go to the secondary level. Secondary education is comprised of two levels, being junior cycle / lower secondary and senior cycle / upper secondary. Students who complete lower secondary education enter the achievement exam. Therefore, the lower secondary education age range is from 12 to 15 years; upper secondary education covers the age range of 15-18. The reason for the differentiation of upper secondary education into two or three years is the transition year. Students who have completed lower secondary education can receive transition year education if they want while going to upper secondary education. The transition year practice offers students the opportunity to experience a wide range of educational subjects, including work experience (www.education.ie; ec.europa.eu). Schools at the secondary level are classified into three groups. These groups are explained below (www.education.ie; ec.europa.eu; www.citizensinformation.ie):

- Secondary schools. These schools belong to and are managed by private individuals or institutions.

- Vocational schools. They are established by the state and are managed by vocational training committees.

- Community and comprehensive schools. The boards of these schools are made up of different components of the society.

Although secondary schools seem to be three different school types, the main difference is related to the structure of the board of directors. In fact, all three of these schools are largely financed by the state and follow similar curricula. At upper secondary level, students follow one of three programs; general, vocational and applied. At the end of the upper secondary level, students enter the achievement 
exams organized by the DES in relation to the program they have attended. These exam results play a very important role in the acceptance of students to higher education institutions. In addition, when the number of secondary schools is examined, it is seen that there are 721 secondary schools in total, including 375 secondary schools, 253 vocational schools, 79 community schools, 14 comprehensive schools (www.education.ie; ec.europa.eu, www.citizensinformation.ie).

Higher education. Students in Ireland go on higher education at the age of 18-19. Higher education is given by 7 universities, 14 technology institutes and 7 education colleges (www.education.ie). In addition, there are independent private colleges. Universities are autonomous and self-governed. University education consists of undergraduate, graduate (3-year ordinary degree or 4-year honor degree) and doctorate programs. Technology institutes offer programs in fields such as business, science, engineering, linguistics, music, and give certificates and diplomas. Technology institutes are under the responsibility of DES (www.citizensinformation.ie). College education is aimed at training lower secondary school teachers. The colleges offer three-year undergraduate and postgraduate diplomas. Colleges are private properties but supported by the state. All colleges are actually affiliated to a university. Management of colleges, staff selection, etc. require the approval of the relevant university. This relationship between colleges and universities has been going on since the 1970s (ec.europa.eu). As mentioned earlier, the scores obtained from the achievement exam are quite effective in the transition to higher education. For example, those who score high on this exam can study medicine or law (martindale.cc.lehigh.edu). In addition, higher education institutions have the authority to decide on accepting students (www.education.ie).

The Higher Education Authority (HEA) is the legal planning and development body for higher education and research in Ireland. HEA advises institutions at tertiary level. It is also responsible for financing institutions at the tertiary level. The Law of Universities, which entered into force in 1997, regulates universities' objectives and functions, structure and management bodies, personnel policies, academic committees and the structure and roles of departments and ownership, finance and reporting. The governing bodies want to see that strategic development plans are being implemented and that the teaching evaluation and research procedures are being implemented. Thus, HEA takes the responsibility of supervising implementation of these plans and quality assurance procedures. The legal structure protects the academic freedom of the universities and respects the different traditional and institutional autonomy of each university (www.education.ie). 
Advanced education and adult education. Advanced education includes education and training given after secondary education. However, advanced education is not part of higher education, that is, tertiary education (www.citizensinformation.ie). This education includes post-leaving certificate courses; Opportunity Programs for Vocational Training (this program includes "second chance" training for the unemployed), programs for early school dropouts; adult literacy, community education, evening training courses, other cultural and basic education courses. The majority of these programs are prepared by DES and are implemented on a full-time or part-time basis. Such programs can be provided by public organizations, as well as by voluntary people and social organizations (DES, 2002; www.citizensinformation.ie). As can be seen, there are many opportunities for people outside of formal education in Ireland to develop themselves. This can also be regarded as an indication of the importance attached to continuing education by the state. As a matter of fact, Ireland is trying not only to educate young people but also to provide continuing education to adults. The state develops policies to involve adult individuals in a systematic way in education and training. The "White Book on Adult Education" published in 2000; for example, is an initiative started in this context. In this way, efforts are invested to achieve goals such as involving adults in advanced education and tertiary level education, helping them to be a part of labor force and educating the society in general (DES, 2002).

Special education. The educational needs of students with disabilities are provided either through private schools or by providing additional support for these students in normal schools. Students with disabilities can study in integration classes or special classes with additional support in normal schools. On the other hand, according to the types of disabilities they can also go to the existing special education schools. The general policy of the state on special education is to integrate students with disabilities with other students as much as possible and to make them study together (www.citizensinformation.ie).

\section{Process Dimension of Irish Education System}

In this section, education and training processes related to the Irish Education System, training of students, training of teachers, supervision and financing of education are examined.

Educational and instructional processes. In Ireland, children aged 6 years old are required to begin primary education. Primary education aims to provide children with a rich learning experience; thus, the implementation of different educational and teaching approaches that will meet the different needs of children are supported. 
Indeed, in Ireland the curriculum was renewed in 1999. The renewed curriculum was designed to contribute to the all aspects of child development; psychological, moral, cognitive, emotional, creative, aesthetic, social and physical. The main subject areas addressed in the curriculum are as follows (www.education.ie):

- Language (Irish and English),

- Math,

- Social, environment and scientific education,

- Arts education (visual arts, music and drama),

- Physical education,

- Social, personality and health education,

In Ireland, children go to schools in their own districts. On the other hand, the Education Act stipulates that families can send their children to the denominational school in order to protect their religious values. Schools have to be equal and fair when accepting students. Families whose children are not accepted to the school they desire may appeal to school boards or DES. Schools are usually at a reasonable distance from students' home. In 1967, DES made school transportation plan in order to make it easier for children living in low-populated areas to have access to education. In this context, until 2011, students who lived at least $3.2 \mathrm{~km}$ away from the school commuted to the school on the service busses of DES free of charge. However, after 2012, the state has begun to charge certain fees to families according to the distance from the school to the house (ec.europa.eu).

The number of students for per teacher at elementary school level is 16.4. The average number of students for per class is 24.7. Apart from private schools, all primary schools are governed by the rules centrally determined by DES. Each primary school has to give at least 183 days of education per year. Students go to school five days a week from Monday to Friday. Since 2003-2004 school year, the DES and the Irish National Teachers' Organization have taken a joint decision and put the "standard school year" into force. Thus, students have three types of holidays that are Christmas, Easter and semester holidays. Throughout the country, all primary schools operate between 09:20 and 15:00. In rural areas, however, classes can begin half an hour earlier. There are at least four hours of lessons per day in primary schools. Besides, extra time is allocated to activities such as taking attendance, eating and religious instruction. Lunch break is half an hour and each break is 10 minutes (ec.europa.eu).

Students who have completed primary education begin lower secondary education at the age of 12 . In secondary education, as in the case of primary education, parents have the right to send their children to the school they wish in accordance with their 
religious values. Schools may carry out some tests to determine the level of students and the students who need special support, but they cannot use these test results while deciding the acceptance of students to schools (ec.europa.eu).

It can be said that all lower secondary schools in Ireland are integrated into a general education program. Eight learning areas are emphasized in the lower secondary education program. These are language and literature, mathematical studies, science and technology, social, political and environmental education, arts education, physical education and counseling and pastoral care and religious and moral education. Since 2012, a holistic approach has begun to be adopted in lower secondary education. Organizations at this level are expected to organize a program to contribute to critical thinking skills, arithmetic and literacy skills of their students. Students must take at least eight courses and no more than 10 courses to finish secondary school. In addition, students have the opportunity to take two short courses that are accepted in place of one course on condition that the certificate of the courses is provided. For example, students can take a variety of courses such as Chinese, digital media literacy but they can take maximum four short courses. Schools may also open their own courses in accordance with the rules set by DES. For example, they can open various courses in the field of agriculture in line with regional needs. It is also aimed to teach the English, Irish and mathematics courses in the upper levels of the students in Ireland and to teach the other courses at the normal level (ec.europa.eu).

Students who have completed lower secondary education may receive transition year education depending on their wishes as they pass to upper secondary education. As mentioned earlier, in this way, students can find the opportunity to have experience in a wide range of educational fields, including work experience (www.education.ie). In upper secondary education, students have the option of studying in three different programs. These programs are explained below (www.education.ie; www.citizensinformation.ie; ec.europa.eu).

- General completion program. It lays the ground for students to receive training at universities, colleges and institutes. There are more than 30 courses in its curriculum. Students must select at least five courses. One of these courses must be Irish.

- Vocational completion program. It is similar to the general completion certificate program; yet, this program mostly focuses on vocational courses and includes some occupation-centered additional modules.

- Applied completion program. It is for students who are not qualified to enter other programs, including an individual-centered education. The primary goal of these programs is to prepare students for adult and working life by 
offering appropriate learning experiences. In this context, they aim to develop students from spiritual, intellectual, social, emotional, aesthetic and physical aspects. Applied completion program does not provide direct transition to third level education. However, there are several courses that students can take after completing this program and this program allows students to participate in these courses.

After completing upper secondary education, students enter the achievement exam organized by DES according to the program they have taken. The achievement exam is used as an election tool both in transition to tertiary education and employment of graduates (ec.europa.eu).

Secondary schools generally have five days of instruction per week and must be open for at least 167 days per year. Some schools offer 6 days of instruction a week. These schools must be open at least 187 days a year. Unlike primary schools, secondary schools allow 13 days for the application of achievement exams to students. The other official holidays are being implemented at the same time as primary schools in the country. Although some schools in the secondary education are open 6 days a week, the majority of the schools usually work 28 hours a week. Schools are open from 09:00 to 16:00 in general, although there are some differences. Usually the length of a class hour varies between 35 and 40 minutes. Class hours are at the discretion of the school administration (ec.europa.eu).

Teacher training. In Ireland, the training processes of teachers who are trained to work in primary and secondary schools differ from each other. Teachers trained to work in secondary schools usually complete first level undergraduate studies at universities; then, they receive the diploma of higher education. At the primary education level, teachers holding bachelor's degree by completing a three-year education in education colleges work (Marlow-Ferguson, 2002). However, it should be noted that there are multiple training options for those who want to become teachers. For example, individuals who are not the graduates of education colleges but holding a diploma in the field of education or a diploma recognized by DES can also work in primary schools (www.citizensinformation.ie). In addition, students who receive teacher education are employed as "student teachers" in designated schools for 10-30 weeks depending on what kind of teaching they will perform (The Teaching Council, 2011).

Individuals who have completed the training required for teaching are required to register at the Teaching Council, which is under the responsibility of DES, in order to actively act as a teacher. This council assesses whether applicants are qualified enough to provide courses in the curriculum. Teacher recruitments for a school are 
determined according to the number of students in that school. In general, it is desirable that the number of students per teacher is 19 and teacher recruitments are made accordingly. Schools may prefer to hire teachers for only certain class hours or specific courses depending on their needs. A school that needs a teacher will advertise on its official website. The teacher who wants to work in that school interviews with the school board or the vocational education committee if it is a vocational school. If agreement is reached, a contract is signed between the parties stating the duration and conditions (full-time and part-time) of the employment. In general, it is difficult for novice teachers to find a permanent and full-time position. These teachers are hired to replace teachers on leave or to teach a few hours a week (www.asti.ie).

Training of school administrators In Ireland, school principals are the ones primarily responsible for the management of schools. Principals work with one or more assistant principals depending on the size of the school. It is necessary to have at least five years of teaching experience at the relevant level of education in order to be a principal in a school. Though it is not a legal requirement, it is expected that the candidates for principalship should have a master's degree in educational administration. Selection of school principals is based on merit, taking into account experience, competence and achievement criteria. The process of appointing principals to schools is as follows: Schools that need principals advertise the position. After official announcements are made, applicants apply to the election board with their resumes. Interviews are held by the electoral committee; candidates have the right to make a presentation if they wish. Then the members of the electoral committee prepare a report about the candidates and present them to the school management board. Selected candidate principals serve as one year trial. Then, if they prove to be qualified enough, they are appointed as tenured teachers (ec.europa.eu). While in the past what was expected from teachers was to exhibit a conception of management focused on education and instruction, recently these expectations increased to cover issues such as leadership, personnel management, communication skills and financial and legal accountability (ec.europa.eu). In this context, school principals in Ireland participate in non-compulsory career development courses. These courses are as follows (Erden \& Erden, 2005);

- Courses and in-service training courses organized by DES in summer months to develop management and leadership roles.

- Courses organized by different teacher centers during the academic year.

- Courses offered by universities.

School principals are responsible for the daily management of the school. In this connection, they set the goals of the school, develop strategies in cooperation 
with the school personnel to be successful, form policies to implement the curriculum, take the leadership role in the preparation of the school plan, assign duties to teachers, evaluate students and encourage teachers for professional development. In addition to these, principals, if needed in primary schools, teach as well as administer. However, in spite of all these responsibilities, salaries of principals are almost at the same level as teacher salaries. Therefore, the number of applications to the principalship is gradually decreasing (ec.europa.eu).

Inspection of education. In Ireland, it is the responsibility of DES to monitor and assess state-recognized schools and education centers in terms of quality and efficiency, structure and effectiveness (ec.europa.eu). DES makes the inspection of education through its own Inspection Board. The Inspection Board is led by a chief inspector and the chief inspector has two assistants. One of the assistants is responsible for the control of primary education and the other is responsible for secondary education. There are three departments in within the Inspection Board, namely "primary education department", "secondary education department" and "psychological services department” (Kasapçopur, 2007). Inspectors who provide legal links between the ministry and schools have three main tasks (www.citizensinformation.ie): Monitoring and evaluating primary and secondary schools; advising and guiding education staff; contributing to the development of educational policies.

The primary focus of inspection in pre-school education is on fulfilling health and safety standards. The main criteria for inspecting primary schools are the quality and effectiveness of teaching, measurement of educational standards, meeting the needs of children in need of special education and compliance with the relevant regulations. Prepared inspection reports are given to the school administration, families and teachers aside from the Ministry. Every six years, all schools are undergone detailed and full supervision (İlğan, 2013). In addition to this, there are also frequent smallscale inspection visits (www.citizensinformation.ie). Inspectors advise teachers on issues such as instructional methods, performance enhancement etc. In secondary education, teachers are evaluated by content inspectors. Lesson plan, lesson preparation and presentation, communication between student and teacher are the main issues to be considered in the inspection of secondary education (İlgan, 2013). In addition, psychologists working in the department of psychological services of the Inspection Board provide counseling services by working individually with the students, parents, teachers and school administrators (Erginer, 2009).

In Ireland, the inspection is largely built on the external inspection of inspectors. In recent years, however, schools have been encouraged to conduct self-assessments, and inspectors also consider whether schools are self-evaluating when conducting their inspection (ec.europa.eu). 
Financing of education. According to 2012 data, the amount spent by the government for educational services is 8.6 billion Euros. This amounts to $16 \%$ of the state's public expenditure. Approximately 3,200 primary-level schools are financed largely by the state. 38 private schools finance themselves. Similarly, almost all of 721 secondary schools are financed directly or indirectly by the state (ec.europa.eu). In this context, the state grants project assistance to each funded school per student, pays teacher salaries, provides additional assistance to schools where students with disabilities are educated, and makes payments for books and other teaching materials. It also pays for the maintenance expenditures of schools (www.citizensinformation.ie).

There are a total of 33 institutions in higher education. Fifteen of them are private; they provide their own finance. However, the other 18 higher education institutions are largely financed by the state. In the same way, the state is organizing programs for young people who have left their education and want to improve themselves, monitoring these programs for effectiveness and financing them (ec.europa.eu). In short, the costs of the institutions at all levels of education are largely met by the Irish state. This is an indication of how much the state has placed importance on education.

\section{Results and Implications for the Turkish Education System}

When compared, it is seen that there are many different and similar sides of the Irish and Turkish education systems. For example, in Ireland, DES and in Turkey, the Ministry of National Education (MEB), is primarily responsible for education and instruction, they have a centralized management approach. In Ireland, however, DES is in a constant interaction with stakeholders such as student unions, nongovernmental organizations, and professional organizations and so on; it involves them in the decision-making process and policy-setting process. However, it is not possible to say that MEB is in cooperation with educational stakeholders to such an extent in Turkey. Despite the fact that DES has a centralized structure, schools have the right to form their own staff within certain rules, while school staff in Turkey are created through central appointments. Thus, it can be asserted that the centralized structure in Turkey is more rigid.

Irish and Turkish education systems differ in terms of the duration of compulsory education, but they are similar in terms of funding of compulsory education. In Ireland, compulsory education includes primary and lower secondary education, lasts nine years and is free. In Turkey, compulsory education covers primary, secondary and high school education, lasts a total of 12 years and is free of charge. 
In Ireland, the right of families to send their children to any school they wish at primary and secondary levels and the right to teach their children at home are legally guaranteed. Application in person must be made in order for the child to be admitted to a school. In Turkey, however, families have to send their children to primary school closest to where they reside, and students are centrally placed to schools. Moreover, families do not have the right to educate their children at home in Turkey.

In the Irish Education System, education prior to higher education is structured as 6 $+3+3$ or $6+3+2$. Primary education is six years, lower secondary education is three years and upper secondary education is two or three years. There is a transition year education that students can take of their own volition when they are passing from lower secondary to upper secondary education. This transition year provides students with many experiences including professional experiences so that it helps them to decide what to do. In Turkey, the compulsory education is structured as $4+$ $4+4$ and it is a fact that guidance and counseling services offered to students are very limited.

Perhaps the most striking feature of the Irish Education System is the lack of a secular educational system. In Ireland schools are heavily influenced by church or religious communities. In Turkey, it is not possible for schools to be managed by any congregation, including schools that offer religious education because it is not legally permitted. Thus, there is a secular education system in Turkey.

Another remarkable difference in the Irish and Turkish Education System is related to the management structure of schools. In Ireland, school management is made up of school owner, board and principal. The board of directors is usually composed of representatives of the school owner, the school principal, teacher representatives and two members representing the community. The board of directors is held responsible for the formation of staff and compliance with regulation; the school principal is responsible for the daily functioning of the school. In Turkey, there is no board of directors in the schools, and all the authority and responsibilities of the school are practiced by the school principal. Thus, it is possible to say that while in Ireland schools function within a system in which education stakeholders participate in governance through the board of directors, in Turkey education stakeholders are not involved in management.

In order to become a school principal in Ireland, at least five years of teaching experience and though not a must, master's degree is required. The school boards are appointing their own principals as a result of the interviews. If the school principal is successful at the end of the one-year trial period, then he/she is appointed as a tenured principal. With the regulations made in Turkey in 2015, to be a school 
principal, it is necessary to have served for a certain period of time as the assistant principal, authorized teacher or at some top positions in the Ministry. Principal candidates are centrally appointed after they have been subjected to an oral test by a central electoral commission. Schools have no say in choosing their own principals.

According to Irish 2012 statistics, 5.6\% of Gross Domestic Product (GDP) is allocated for education and $4.4 \%$ of these expenditures are made to educational institutions before university and $1.2 \%$ for tertiary level education. In Turkey, the total amount of allocation to education is $4.4 \%$ of GDP and $3.0 \%$ of it is for educational institutions before university and $1.4 \%$ for tertiary level (The Organization for Economic Co-operation and Development [OECD], 2015). As can be seen, Ireland allocates more money to education than Turkey.

In Ireland, the schooling rate in the 15-19 age range is $96.7 \%$, while the schooling rate in the 20-29 age range is $22.1 \%$. In Turkey, the schooling rate in the 15-19 age range is $69.1 \%$ and the schooling rate in the age range $20-29$ is $30.1 \%$. From these data, it is clear that the participation rate in secondary education in Ireland is higher than in Turkey; yet, the rate of enrollment in higher education is higher in Turkey (OECD, 2016).

In Ireland, students in secondary education enter the achievement exams organized by DES according to the program they have attended. The grades they receive from the achievement exams are effective in their acceptance into higher education institutions; but there are other criteria. Higher education institutions may set different conditions for accepting candidates. Candidates must apply individually to the higher education institution they wish to attend. In Turkey, students who have completed secondary education enter a central university entrance exam. However, there is no individual application to higher education institutions; instead, candidates are subject to the centralized placement procedure according to the score they receive from the examination and their preferences.

In Ireland, HEAs are responsible for the planning, development and financing of higher education. In Turkey, these functions are performed by the Higher Education Council (YÖK). HEA and YÖK are therefore quite similar institutions. In Ireland, understanding of inspection is not based solely on review and control, but the development of education and instruction is of great importance. In addition to detailed full-school assessments made at 6-year intervals, there are often small-scale inspections. In addition, psychologists within the Inspection Board are individually involved in the development of school staff and students. When the conception of inspection adopted in Turkey is examined, it is seen that development of inspection has been neglected to a great extent. Moreover, it is not possible to mention the 
inspections conducted frequently in Turkey. Schools are encouraged to conduct selfassessments, despite the fact that they are heavily externally supervised in Ireland. Though external inspection is practiced in Turkey as in Ireland, it is not possible to mention self-assessment practices. It may also be useful to include psychologists in the inspection units of Turkey as in Ireland.

As a result, Irish and Turkish education systems have many similar features such as having a centralized structure, students being subject to the test at the end of secondary education, funding of educational institutions largely governed by the state, external control of the schools being predominant and control of educational institutions such as YÖK and HEA on higher education. On the other hand, these two systems differ in terms of the school's management structure, the duration of compulsory education, the understanding of secular education, the right of families to send their children to school they wish and provide education at home, the allocation of resources to education, the appointment of principals and the participation of education stakeholders. As a result of comparison of these two education systems it is possible to say: It is clear that providing more opportunities for stakeholders to participate in the administrative processes, involvement of psychologists in the inspection units, emphasis on self-evaluation and giving more counseling and guidance to students will contribute to the development of the education system in Turkey.

\section{References}

DBTM, (2010). The economy of Ireland and the economic and commercial relationships between Turkey and [Ireland Irlanda ekonomisi ve Türkiye ile ekonomik ve ticari ilişkileri]. Retrieved April 10, 2016, from www.een.kso.org.tr/up/dene/IRLANDAULKERAPORU.doc.

DES, (2002). A brief description of the Irish education system. Retrieved April 10, 2016, from https://www.education.ie/en/Publications/Education-Reports/A-BriefDescription-of-the-Irish-Education-System.pdf.

Erden, A. ve Erden, H. (2005). Avrupa Birliği ülkelerinde okul yöneticileri. Milli Eğitim Ü̧̧ Aylık Eğitim ve Sosyal Bilimler Dergisi 33 (167). Retrieved April 16, 2016, from http://dhgm.meb.gov.tr/yayimlar/dergiler/Milli_Egitim_Dergisi/167/index3erden.htm

Erginer, A. (2012). The European Union education systems [Avrupa Birliği eğitim sistemleri]. (3rd ed.). Ankara: Pegem A Publishing.

İlğan, A. (2013). Irish education system [İrlanda eğitim sistemi]. A. Balcı (Ed.). Comparative educational systems (4th ed.). (pp.273-286). Ankara: Pegem A Publishing. 
Ireland Central Statistical Office, (2015). Population and migration estimates. Retrieved April 12, 2016, from

http://www.cso.ie/multiquicktables/quickTables.aspx?id=pea01.

Istanbul Chamber of Commerce, (2009). Ireland country report [Irlanda ülke raporu]. Retrieved April 2, 2016, from http://www.ito.org.tr/Dokuman/Ulke/Irlanda.pdf.

Kasapçopur, A. (2007). Educational inspection in the country of the European Union [Avrupa Birliği ülkelerinde eğitim denetimi]. Ankara: Ministry of Education Inspection Board.

Marlow-Ferguson, R. (2002). World education encyclopedia: A survey of educational systems worldwide. Farmington Hills, USA: Gale Group.

Ministry of Economy, (2014). Ireland/Overview [Ireland/Genel bilgiler]. Retrieved April 2, 2016, from http://www.ekonomi.gov.tr/portal/faces/home/disIliskiler/ulkeler/ulkedetay/\%C4\%B0rlanda/html-viewer-ulkeler?

Ministry of Foreign Affairs, (2016). The economy of Ireland [Irlanda'nin ekonomisi]. Retrieved April 10, 2016, from http://www.mfa.gov.tr/irlanda-ekonomisi.tr.mfa

Ministry of Justice, (2011). Constitution of Ireland [Irlanda Anayasası], Retrieved April 12, 2016, from http://www.adalet.gov.tr/duyurular/2011/eylul/anayasalar/ulkeana/pdf/09 $\%$ C4\%B0RLANDA\%20277-318.pdf

OECD, (2015). Education at a Glance 2015: OECD indicators. Retrieved April 18, 2016, from

http://www.oecdilibrary.org/docserver/download/9615031e.pdf?expires=1460989

$867 \&$ id=id\&accname $=$ guest $\&$ checksum $=2 B 1 E 68 C 68$ ABA38FBF90D58CA2A 4358 F0

OECD, (2016). Enrolment rate (indicator). Retrieved April 18, 2016, from, https://data.oecd.org/eduatt/enrolment-rate.htm\#indicator-chart.

Şöhret, M. (2013). The Irish problem in the context of ethno-religious nationalism [Etnodinsel milliyetçilik bağlamında İrlanda sorunu]. Journal of the Human and Social Science Researches 2 (4), 39-76.

The Teaching Council, (2011). Initial Teacher Education: Criteria and Guidelines for Programme Providers. Retrieved April 16, 2016, from http://www.teachingcouncil.ie/en/Publications/Teacher-Education/Initial-TeacherEducation-Criteria-and-Guidelines-for-Programme-Providers.pdf

Yeter, A. H. (2004). Examination of the objectives, scope and methods of structural funds within the sample country applications. Expertise thesis, The Secretariat General for the EU Affairs, Ankara.

\section{Electronic resources}

mavoieproeurope.onisep.fr. http://mavoieproeurope.onisep.fr/en/initial-vocationaleducation-and-training-ieurope/ireland. Retrieved April 10, 2016.

Asti.ie. http://www.asti.ie/pay-and-conditions/new-to-teaching/considering-a-career-inteaching/. Retrieved April 10, 2016.

Citizens Information. http://www.citizensinformation.ie/en/education/primary_and_post_primary_educati 
on/going_to_primary_school/ownership_of_primary_schools.html 1. Retrieved April 3, 2016.

http://www.citizensinformation.ie/en/education/primaryandpostprimaryeducation/teachersa ndschools/schoolsinspectorate.html. Retrieved April 3, 2016.

http://www.citizensinformation.ie/en/education/the_irish_education_system/overview_of_t he_irish_education_system.html. Retrieved April 15, 2016.

http://www.education.ie/en/The-Education-System/Primary/\#sthash.k3DX01U8.dpuf Retrieved April 15, 2016.

https://martindale.cc.lehigh.edu/sites/martindale.cc.lehigh.edu/files/Carone.pdf_Retrieved April 10, 2016.

https://webgate.ec.europa.eu/fpfis/mwikis/eurydice/index.php/Ireland:Quality_Assurance Retrieved April 15, 2016.

https://webgate.ec.europa.eu/fpfis/mwikis/eurydice/index.php/Ireland:Overview Retrieved April 15, 2016.

https://webgate.ec.europa.eu/fpfis/mwikis/eurydice/index.php/Ireland:Secondary_and_PostSecondary_Non-Tertiary_Education_. Retrieved April 16, 2016.

https://webgate.ec.europa.eu/fpfis/mwikis/eurydice/index.php/Ireland:Organisation_of_Upp erSecondary_Education Retrieved April 16, 2016.

https://webgate.ec.europa.eu/fpfis/mwikis/eurydice/index.php/Ireland:Types_of_Higher_Ed ucation_Institutions_Retrieved April 15, 2016.

https://webgate.ec.europa.eu/fpfis/mwikis/eurydice/index.php/Ireland:Management_and_Ot her_Education_Staff. Retrieved April 15, 2016.

https://webgate.ec.europa.eu/fpfis/mwikis/eurydice/index.php/Ireland:Organisation_and_G overnance. Retrieved April 15, 2016.

https://webgate.ec.europa.eu/fpfis/mwikis/eurydice/index.php/Ireland:Primary_Education Retrieved April 17, 2016.

https://webgate.ec.europa.eu/fpfis/mwikis/eurydice/index.php/Ireland:Funding_in_Educatio n Retrieved April 17, 2016.

https://www.education.ie/en/The-Department/Management-Organisation/Inspectorate.html Retrieved April 15, 2016.

https://www.education.ie/en/The-Department/Management-Organisation/. Retrieved July 4, 2017. 


\title{
Summary
}

\section{The Irish Education System and Implications for the Turkish Education System}

\author{
Nuriye Karabulut \\ Faculty of Educational Sciences, Ankara University, Turkey
}

The purpose of the current study is to make a detailed introduction to the Irish education system and to come up with some implications latter through comparing it with the Turkish education system. Accordingly, the literature was reviewed. A general introduction was made to Ireland and its education system was examined considering its goals, structure and process dimensions. Similar and different aspects of the Irish and Turkish education system were discussed, and various suggestions were developed. The Irish and Turkish education systems have many similarities in terms of having a centralized structure, students' obligation to take a general exam at the end of secondary education, financing of schools mostly by public resources, dominance of external inspection at schools and control of higher education by higher education councils such as YÖK and HEA. On the other hand, these two systems differ from each other in terms of administrative structure of schools, time of compulsory education, secular structure of education, rights to send children to whichever school they wish and to educate children at home, financial resources allocated for education, appointment of school principals and participation of stakeholders in administration. As a result of the comparison of these two education systems, it can be said that more opportunities should be provided for stakeholders to take part in administrative processes, psychologists should be included in inspection units, more emphasis should be put on self-assessment and more guidance and counseling should be offered to students so that the education system in Turkey can develop more.

Keywords: Ireland, Irish education system, Turkish education system 